Томчук О. В. ${ }^{[1 ; 0 R C I D ~ I D: ~ 0000-0002-1817-7483] ~}$ к.е.н., доцент

'Донецький національний університет імені Василя Стуса, м. Вінниця

\title{
КОНЦЕПТУАЛЬНІ ПОЛОЖЕННЯ ФОРМУВАННЯ СТРАТЕГІЇ РОЗВИТКУ ЛЮДСЬКОГО ПОТЕНЦІАЛУ МІСТ В НОВІЙ ЕКОНОМІЦІ
}

Статтю присвячено висвітленню питань стратегічного розвитку людського потенціалу міст в контексті становлення нової економіки, подолання новітніх постіндустріальних, інноваційно-технологічних, викликів людиноцентрованого розвитку суспільства, визначенню ролі людського потенціалу у перетворенні міст на динамічні центри соціальноекономічного розвитку. Проведено оцінку стратегічних пріоритетів найбільш конкурентоспроможних міст України та визначено, які аспекти при формулюванні стратегічного бачення розвитку міста позитивно відображаються на формуванні людського потенціалу. Обґрунтовано необхідність консолідації зусиль щодо формування комфортного міського середовища, направленого на формування, збереження, розвиток і ефективне використання людського потенціалу міст, а отже, набуття ним такого характеру, що сприяє максимальному розкриттю індивідуальних можливостей носіїв людського потенціалу незалежно від територіального походження. Сформульовано ключові положення ефективного формування стратегії нарощення людського потенціалу на сучасному етапі розвитку соціально-економічних відносин.

Ключові слова: стратегічний розвиток; людський потенціал міст; постіндустріальна економіка; конкурентоспроможність міст.

Постановка проблеми. Людський потенціал позиціонується в постіндустріальному суспільстві у якості найвищої цінності і важливого стратегічного ресурсу, ефективність формування, збереження та подальше використання якого визначає рівень розвитку будь-якої соціально-економічної системи. Особливістю людського потенціалу як ключового ресурсу при здійсненні стратегічного планування як на національному, так і на місцевому рівні виступає його подвійна природа - 3 одного боку, люди створюють матеріальні та нематеріальні блага, а 3 іншого споживають їх, а отже, виступають у якості визначального стимулу для зростання, покращення умов і комфорту життєдіяльності, загального соціально-економічного добробуту. Водночас реалізація людського потенціалу веде не до його зменшення, а навпаки - до зміцнення та нарощення, дозволяючи йому зберігати свої 
можливості і створювати нові у довготривалій перспективі. 3 огляду на те, що сучасні тенденції світового розвитку характеризуються високим рівнем непрогнозованості та невизначеності, виникненням неочікуваних кризових явищ, які посилюються у форматі ланцюжкових реакцій в контексті глобалізації, концентрація уваги переміщується на локальний рівень формування людського потенціалу. Окремі території та міста перетворюються на точки стійкого зростання для досягнення високої національної конкурентоспроможності, розвинутого внутрішнього ринку, інноваційного характеру національного виробництва, що спирається насамперед на людський потенціал територій та міст за умов формування комфортного середовища для розвитку усіх його складових. Одночасно з тим місцевий територіальний розвиток характеризується сьогодні високим рівнем асиметричності і розбалансованості, в результаті чого умови формування людського потенціалу міст доволі часто $є$ недостатніми для максимально повної його реалізації. Стратегічне планування розвитку людського потенціалу міст покликане підвищити наукову обґрунтованість та практичну значущість цілей, управлінських рішень, прогнозних сценаріїв та програм місцевого розвитку з метою більш повного врахування інтересів та потреб носіїв людського потенціалу, спроможного забезпечувати довготривалу якісну динаміку місцевого і національного зростання.

Аналіз останніх досліджень і публікацій. Питання, присвячені визначенню ролі людського потенціалу у соціально-економічному розвитку, розглядаються багатьма дослідниками та науковцями (Т. Шульц [1], Г. Беккер [2], О. Грішнова, В. Антонюк, Р. Яковенко [3], Л. Шаульська [4], Р. Капелюшнікова, А.Докторович, Л. Семів, Н. Непрядкіна [5]), які у своїх працях докладно характеризують теоретичні та методологічні підходи щодо визначення його сутності, рівнів формування, складових елементів та методів оцінювання. Проблематика територіального розвитку розглядається в роботах Д. Джекобса, М. Спенса, М. Кастельса, Д. Харві, Л. Джанга [6], О. Шаблій, М. Мельник, В. Жук, М. Кушнір, К. Осипенко [7], де відзначено зростання значущості міст та територій в глобальному вимірі, можливості їх включення у міжнародні ланцюжки створення вартості, перетворення міст на центри економічного і соціального зростання. Окремо розглядаються питання стратегічного планування та містоутворення, менеджменту територій, реалізації програм та проєктів, направлених на підвищення якості життя в містах та досягнення локальної стійкості (Т. Пойстер [8], К. Рейнор [9], 
А. Вілсон [10], К. Мезенцев [11], Т. Збрицька, К. Бліщук [12], В. Бойченко [13]). Одночасно з тим, проблеми формування людського потенціалу міст, визначення ключових аспектів, що обмежують максимально повне його використання в новій економіці, а також формулювання механізмів його стратегічного розвитку залишаються недостатньо дослідженими та потребують додаткової уваги.

Формулювання цілей статті. 3 огляду на вищенаведене метою дослідження $€$ наукове обгрунтування концептуальних положень формування стратегії розвитку людського потенціалу міст 3 урахуванням викликів нової економіки та постіндустріального суспільства.

Виклад основного матеріалу. Сучасний характер соціальноекономічних відносин визначається становленням постіндустріального типу виробництва і створення вартості, коли інформація і знання виступають у якості нового виробничого ресурсу, що $є$ формою реалізації та примноження людських здібностей [14]. Унікальні людські можливості проявляються в процесі трансформації праці та їі суспільного значення, водночас технологічні рішення постіндустріальної економіки дозволяють зменшити обсяг трудового навантаження на людину, одночасно підвищуючи вимоги до іï якісних характеристик. В концепції людського потенціалу розвиток людини виступає не просто засобом підвищення продуктивності, а кінцевою метою господарської діяльності та суспільних відносин, підвищуючи значущість застосування дієвих механізмів для здійснення комплексної трансформації людини відповідно новітніх вимог на основі зростання інтелектуального, соціального і духовнокультурного рівня, творчої і особистісної реалізації [15].

Узагальнюючи трактування різних дослідників щодо ролі людського потенціалу у забезпеченні сталої соціально-економічної динаміки [1-5; 15-16] відзначимо, що людський потенціал спроможний забезпечувати формування головної продуктивної сили для зростання економіки, створювати сприятливі умови для підвищення рівня і комфорту життя, виступати глобальною категорією потенційного стратегічного розвитку і досягнення високого рівня національної конкурентоспроможності. 3 огляду на те, що в концепції сталого розвитку ключовими драйверами економічного піднесення виступають міста та території, на перший план висувається можливість концентрації та диференціації економічної діяльності, збільшення радіусу регіонального впливу не тільки великих, але й середніх міст, розширення значущості міст до рівня міжнародних економічних агентів, а отже, посилюються інтеграційні процеси територіальної організації суспільства (процеси 
територіального розміщення, спеціалізації та інтегрування) [19]. В цьому аспекті максимально повне розкриття людських можливостей виступає ключовим ресурсом у забезпеченні ефективного перебігу цих процесів. Враховуючи подвійну природу людського потенціалу досягнення цієї мети визначається можливістю сформулювати адекватне середовище для його формування, збереження, відтворення та використання на локальному рівні, що в сучасних українських реаліях представляється складним завданням з огляду на негативні демографічні процеси, значну деформацію соціального середовища, довготривалі кризові явища, наявність асиметрій у регіональному розвитку.

Зазначені проблеми призводять до формування у носіїв людського потенціалу негативних поведінкових патернів, коли основні зусилля щодо особистісного розвитку концентруються не на максимальній творчій самореалізації, а на забезпеченні принаймні неубутного існування, підпорядкуванні власних цілей інтересам домінуючих соціально-економічних систем. В цьому контексті узгодження цілей людського і територіального розвитку покликане подолати існуючий дисбаланс, сформувати цілісне бачення щодо нової, соціально орієнтованої моделі економічного зростання 3 чітким окресленням пріоритетів залучення і розподілу ресурсів, використання наявних і формування нових потенційних можливостей гармонійного розвитку кожної особистості.

У більшості розвинених країн рівень розвитку людського потенціалу та ключові показники його оцінювання виступають загальноприйнятою практикою при здійсненні стратегічного планування розвитку міст [20]. Однак, здебільшого, включення терміну «людський потенціал» у якості пріоритетів стратегічного соціально-економічного розвитку міст виявляє підміну понять або ж недостатньо повне розкриття концептуальних можливостей категорії.

Доволі часто у формулюванні стратегічних цілей та пріоритетів людський потенціал розуміють у якості сфер та інститутів соціального забезпечення, які визначають комфорт та якість проживання, рівень добробуту населення, а при визначенні проблем та загроз спостерігається певна зверхність, так само як і при формулюванні заходів щодо цілеспрямованого розвитку людського потенціалу міст. Водночас заходи та програми, більш конкретизовані щодо цільових об'єктів застосування, дозволяють зафіксувати цільові аудиторії і досягти більшої реалістичності, валідності індикаторів стратегічного розвитку міст, моделювати сприятливі для людського розвитку умови. 
У світовій практиці найбільш деталізованими є верхньорівневі стратегії міст Нью-Йорк та Лондон, які складаються з більш ніж 350 сторінок та повинні містити основні регуляторні заходи та детальне обґрунтування їх досягнення (рис. 1).

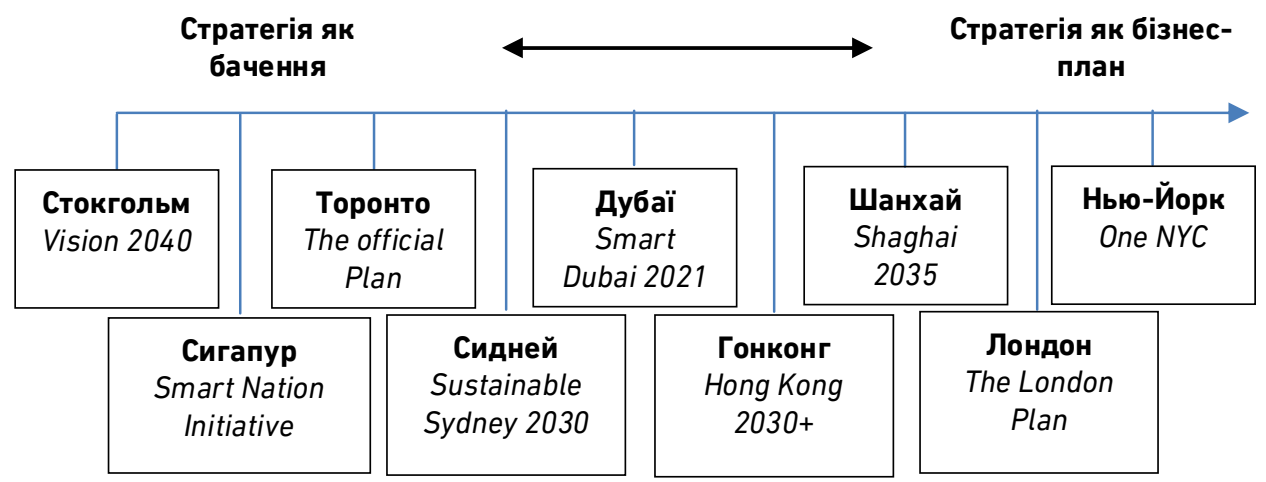

Рис. 1. Розподіл стратегій розвитку найбільших світових міст за рівнем Джерело: [21]

Так за результатами аналізу індексу конкурентоспроможності українських міст 2019/2020 [22] лідируючі позиції зайняли міста, у напрямах стратегічного розвитку яких концепція людського потенціалу $є$ більш конкретизованою за цільовими параметрами та індикаторами. Вибірковий аналіз Стратегій розвитку міст-учасників рейтингу за стратегічними пріоритетами наведено у табл. 1.

Таблиця 1

Аналіз пріоритетів стратегічного розвитку міст в контексті нарощення людського потенціалу

\begin{tabular}{|c|c|c|c|}
\hline $\begin{array}{l}\text { Місце у } \\
\text { рейтингу }\end{array}$ & Назва міста & $\begin{array}{c}\text { Напрями стратегічного } \\
\text { розвитку }\end{array}$ & $\begin{array}{c}\text { Документ, в } \\
\text { якому } \\
\text { опубліковано } \\
\text { стратегію }\end{array}$ \\
\hline 1 & Хмельницький & $\begin{array}{c}\text { А. Місто-підприємець } \\
\text { В. Комфортне та безпечне } \\
\text { місто } \\
\text { С. Відповідальне місто }\end{array}$ & $\begin{array}{c}\text { План дій з } \\
\text { реалізації } \\
\text { Стратегії } \\
\text { розвитку міста } \\
\text { Хмельницького } \\
\text { на 2021-2025 } \\
\text { роки. } \\
\text { Хмельницький, } \\
2020.96 \text { с. }\end{array}$ \\
\hline
\end{tabular}


продовження табл. 1

\begin{tabular}{|c|c|c|c|}
\hline 2 & $\begin{array}{c}\text { Івано- } \\
\text { Франківськ }\end{array}$ & $\begin{array}{c}\text { А. Місто підтримки } \\
\text { інвестицій та розвитку } \\
\text { бізнесу } \\
\text { В. Місто енергоефективної } \\
\text { та дружньої до довкілля } \\
\text { інфраструктури } \\
\text { C. Місто відкритої влади і } \\
\text { сучасного управління } \\
\text { D. Місто якісної освіти, } \\
\text { медицини, } \\
\text { різноформатного } \\
\text { культурного середовища }\end{array}$ & $\begin{array}{c}\text { Стратегія } \\
\text { розвитку міста } \\
\text { Івано- } \\
\text { Франківська на } \\
\text { період до } 2028 \\
\text { року. Івано- } \\
\text { Франківськ, } \\
2017 \text { р. } 56 \text { с. }\end{array}$ \\
\hline 3 & Львів & $\begin{array}{c}\text { А. Виховання креативності } \\
\text { В. Збереження креативних } \\
\text { людей } \\
\text { C. Концентрація } \\
\text { креативних людей } \\
\text { D. Залучення креативних } \\
\text { людей ззовні }\end{array}$ & $\begin{array}{c}\text { Комплексний } \\
\text { план розвитку } \\
\text { Львова - Стратегія } \\
\text { прориву } 2027 . \\
\text { Інститут міста, } \\
2019.31 \text { с. }\end{array}$ \\
\hline 13 & Харків & $\begin{array}{c}\text { А. Цифрове та безпечне } \\
\text { середовище } \\
\text { В. Креативні індустрії } \\
\text { С. Комфортне місто }\end{array}$ & $\begin{array}{c}\text { Стратегія } \\
\text { розвитку міста } \\
\text { Харкова до } 2030 \\
\text { року. URL: } \\
\text { https://www.city. } \\
\text { kharkov.ua/ } \\
\end{array}$ \\
\hline 16 & Суми & $\begin{array}{c}\text { А. Доступність } \\
\text { В. Місто для людей } \\
\text { C. Конкурентоспроможна } \\
\text { економіка } \\
\text { D. Ефективне управління }\end{array}$ & $\begin{array}{c}\text { Стратегія } \\
\text { розвитку міста } \\
\text { Суми 2030. } 2019 . \\
95 \text { с. }\end{array}$ \\
\hline 21 & Київ & $\begin{array}{c}\text { А. Підвищення рівня } \\
\text { конкурентоспроможності } \\
\text { міста } \\
\text { В. Підвищення комфорту } \\
\text { життя мешканців С. } \\
\text { Збереження історичної } \\
\text { самобутності та розвиток } \\
\text { культури } \\
\end{array}$ & $\begin{array}{c}\text { Стратегія } \\
\text { розвитку міста } \\
\text { Києва до } 2025 \\
\text { року. Київська } \\
\text { міська державна } \\
\text { адміністрація. } \\
\text { 2017. } 144 \text { с. }\end{array}$ \\
\hline 22 & Запоріжжя & $\begin{array}{c}\text { А. Місто здорового } \\
\text { довкілля та } \\
\text { ресурсозбереження } \\
\text { В. Місто підприємництва та } \\
\text { креативної економіки } \\
\text { С. Місто зручної, безпечної } \\
\text { та креативної урбаністики } \\
\text { D. Місто високої якості } \\
\text { життя }\end{array}$ & $\begin{array}{c}\text { Стратегія } \\
\text { розвитку міста } \\
\text { Запоріжжя на } \\
\text { період до } 2027 \\
\text { року. Запоріжжя, } \\
2017.63 \text { с. }\end{array}$ \\
\hline
\end{tabular}


Зрозуміло, що подібне узагальнення є умовним, однак місталідери рейтингу, пріоритетами розвитку яких відзначено нарощення економічної активності за рахунок посилення підприємницької та інвестиційної діяльності, стимулювання креативності, доступу до якісних освітніх і медичних послуг, формування комфортних i безпечних умов життєдіяльності, дружньої до довкілля міської інфраструктури, мають більш чітке формулювання предметної та тематичної направленості, а також визначення агентів реалізації ключових завдань стратегічної програми, і в цілому більш наближені до індивідуальних пріоритетів розвитку людського потенціалу.

Одночасно з тим наведені у переліку міста $€$ великими обласними центрами, у яких $\epsilon$ набагато більше ресурсних можливостей, і водночас існує більше обмежень для здійснення ефективного розвитку людського потенціалу. Великі міста згідно IKM [22] є лідерами за структурованістю та доступністю публічних даних, обсягами податків та зборів, але обіймають високі позиції щодо розвитку неформального сектору та рівня корумпованості. Для середніх та невеликих міст характерний більш високий рівень підприємницької активності та безпеки ведення бізнесу завдяки меншій кількості перешкод для реєстрації підприємств, ефективної інформаційно-консультаційної підтримки, наявності налагодженого публічно-приватного діалогу, невисокої вартості дотримання норм законодавства.

Лідерами за якістю людського розвитку $\epsilon$ міста Харків $(8,02$ бала), Івано-Франківськ $(7,70)$, Львів $(6,85)$, Краматорськ $(6,60)$ та Рівне $(6,44)$, де максимальні оцінки отримали показники задоволеності якістю робочої сили та рівнем освіти, хоча було отримано і протилежні твердження (дефіцит кваліфікованої пропозиції на ринку праці, гостра проблема старіння населення, низька тривалість життя та рівень здоров'я тощо). Таким чином, ключові проблеми розвитку людського потенціалу, що $\epsilon$ характерними для території України загалом, залишаються актуальними і на локальному рівні, та потребують стратегічного вирішення та попередження виникнення подібних кризових ситуацій у майбутньому, мають знаходити адекватне відображення у стратегічних планах та програмах розвитку міст не лише у декларативному статусі.

Стратегічне планування розвитку міст повинне бути більш чітко орієнтоване на реалізацію головних принципів сталого розвитку людського потенціалу (сталість, продуктивність, справедливість, співробітництво, рівність, безпека, розширення можливостей), містити валідну термінологію, спиратись на індивідуальні пріоритети 
особистісного розвитку, емерджентність та адресність процесів, спрощувати моніторинг та відстеження результатів.

Куц Ю. та Мамонова В. пропонують виокремлювати два ключові напрямки розвитку людського потенціалу на рівні території або громади: його безпосереднє збереження та розвиток (поліпшення демографічних характеристик, збільшення освітнього потенціалу, стабілізація зайнятості, розвиток інфраструктури, модернізація міського простору) і одночасне нарощення управлінської складової (визначення дієвих способів і заходів активізації спроможностей управлінської системи до постійного оновлення) [23]. У більш пізніх наукових працях подібне трактування набуло розвитку у форматі сприйняття людського потенціалу в якості ресурсів живлення, а управлінської складової в якості ресурсів забезпечення [24, С. 96]. Погоджуючись із наведеним розмежуванням відзначимо, що ці два напрямки $є$ взаємозалежними, оскільки якість людського потенціалу міста визначає ступінь сприйняття його населенням управлінських дій та заходів, направлених на його удосконалення, розуміння політики стратегічного розвитку і визначених нею пріоритетів, забезпечення свідомої участі кожного громадянина у розвитку міста через підвищення особистої відповідальності за досягнутий результат.

При цьому останні дослідження свідчать про потребу більш якісного аналізу ключових потреб носіїв людського потенціалу міст, оскільки вони не тільки розрізняються в залежності від історично складеного функціонального призначення міст, але й формують окремі поведінкові траєкторії відповідно типових особливостей менталітету його мешканців.

Система міст України розрізняється за динамікою чисельності населення та включає динамічні міста (виступають полюсами соціально-економічного зростання, поліфункціональними центрами 3 розвинутою інфраструктурою), стабілізовані (обласні та промислові центри), стагнуючі (адміністративні або монофункціональні центри) та згасаючі (селища міського типу), при цьому нажаль більшість українських міст відноситься до двох останніх категорій [23]. Відповідно наведеної типологізації можна сформулювати характерні проблемні сфери економічного і соціального розвитку міст, що визначають стан середовища та умови формування людського потенціалу (табл. 2). 
Узагальнена оцінка проблемних сфер економічного та соціального розвитку міст України

\begin{tabular}{|c|c|c|c|c|}
\hline $\begin{array}{l}\text { Тип міста } \\
\text { сфера }\end{array}$ & $\begin{array}{c}\text { Динамічні } \\
\text { (Київ, } \\
\text { Харків, } \\
\text { Дніпро, } \\
\text { Львів) } \\
\end{array}$ & $\begin{array}{c}\text { Стабілізовані } \\
\text { (Хмельницький, } \\
\text { Чернівці, } \\
\text { Тернопіль) }\end{array}$ & $\begin{array}{l}\text { Стагнуючі } \\
\text { (Конотоп, } \\
\text { Дрогобич, } \\
\text { Ізмаїл) }\end{array}$ & $\begin{array}{c}\text { Згасаючі } \\
\text { (Фастів, } \\
\text { Шепетівка, } \\
\text { Жмеринка) }\end{array}$ \\
\hline $\begin{array}{l}\text { Середній } \\
\text { дохід }\end{array}$ & $\begin{array}{l}\text { Відносно } \\
\text { висока } \\
\text { ділова } \\
\text { активність } \\
\end{array}$ & $\begin{array}{l}\text { Посередня } \\
\text { ділова } \\
\text { активність }\end{array}$ & $\begin{array}{l}\text { Посередня } \\
\text { ділова } \\
\text { активність }\end{array}$ & $\begin{array}{l}\text { Низький } \\
\text { рівень } \\
\text { ділової } \\
\text { активності }\end{array}$ \\
\hline $\begin{array}{l}\text { Економічна } \\
\text { активність } \\
\text { населення }\end{array}$ & $\begin{array}{l}\text { Відносно } \\
\text { висока } \\
\text { економічна } \\
\text { активність } \\
\end{array}$ & $\begin{array}{l}\text { Посередня } \\
\text { економічна } \\
\text { активність }\end{array}$ & $\begin{array}{l}\text { Посередня } \\
\text { економічна } \\
\text { активність }\end{array}$ & $\begin{array}{l}\text { Низький } \\
\text { рівень еко- } \\
\text { номічної } \\
\text { активності }\end{array}$ \\
\hline $\begin{array}{l}\text { Доступність } \\
\text { освіти }\end{array}$ & $\begin{array}{l}\text { Відносно } \\
\text { доступна та } \\
\text { якісна } \\
\text { освіта }\end{array}$ & $\begin{array}{l}\text { Середня } \\
\text { якість та } \\
\text { доступність } \\
\text { освіти }\end{array}$ & $\begin{array}{l}\text { Низька } \\
\text { якість та } \\
\text { доступність } \\
\text { освіти }\end{array}$ & $\begin{array}{l}\text { Низька } \\
\text { якість та } \\
\text { доступність } \\
\text { освіти } \\
\end{array}$ \\
\hline $\begin{array}{l}\text { Зростання } \\
\text { чисельності } \\
\text { населення }\end{array}$ & $\begin{array}{l}\text { Відносно } \\
\text { позитивна } \\
\text { динаміка } \\
\text { приросту } \\
\text { населення }\end{array}$ & $\begin{array}{l}\text { Позитивна } \\
\text { динаміка } \\
\text { приросту } \\
\text { населення }\end{array}$ & $\begin{array}{l}\text { Негативна } \\
\text { динаміка } \\
\text { приросту } \\
\text { населення }\end{array}$ & $\begin{array}{l}\text { Негативна } \\
\text { динаміка } \\
\text { приросту } \\
\text { населення }\end{array}$ \\
\hline $\begin{array}{l}\text { Якість } \\
\text { медичного } \\
\text { обслуговуван } \\
\text { ня }\end{array}$ & $\begin{array}{l}\text { Доступне } \\
\text { медичне } \\
\text { обслуговув } \\
\text { ання }\end{array}$ & $\begin{array}{l}\text { Відносно } \\
\text { доступне } \\
\text { медичне } \\
\text { обслуговуван } \\
\text { ня }\end{array}$ & $\begin{array}{l}\text { Посередньо } \\
\text { доступне } \\
\text { медичне } \\
\text { обслуговува } \\
\text { ння }\end{array}$ & $\begin{array}{l}\text { Переважно } \\
\text { недоступні } \\
\text { або неякісні } \\
\text { медичні } \\
\text { послуги }\end{array}$ \\
\hline $\begin{array}{l}\text { Безпека та } \\
\text { комфорт }\end{array}$ & $\begin{array}{l}\text { Середній } \\
\text { рівень } \\
\text { безпеки та } \\
\text { комфорту } \\
\end{array}$ & $\begin{array}{l}\text { Високий } \\
\text { рівень } \\
\text { безпеки та } \\
\text { комфорту }\end{array}$ & $\begin{array}{l}\text { Низький } \\
\text { рівень } \\
\text { безпеки та } \\
\text { комфорту }\end{array}$ & $\begin{array}{l}\text { Низький } \\
\text { рівень } \\
\text { безпеки та } \\
\text { комфорту }\end{array}$ \\
\hline
\end{tabular}

Джерело: розроблено автором

В той же час, очікування мешканців міст щодо модернізації існуючого середовища розвитку людського потенціалу та його стратегічної перебудови дещо різняться. На перший план в динамічних містах виходять питання якісного транспортного сполучення (43\%) та організації дозвілля (41\%), тоді як стагнуючі та згасаючі міста насамперед стурбовані можливістю працевлаштування і доступності освіти (34\%), рівнем доходу (29\%) та питаннями безпеки і комфорту (29\%) [25]. Мешканці стабілізованої 
групи міст в цілому однаково стурбовані вирішенням зазначених питань. Більшість вікового населення не готові змінювати існуючий спосіб життя та ставати більш відкритими до культурного розмаїття та розвитку, тоді як молоде населення сприймає зміни позитивно, але за умов відсутності прогресу готове мігрувати до більш успішних динамічних або стабілізованих міст [26-27].

3 огляду на це, ключові положення формулювання стратегічних пріоритетів розвитку людського потенціалу міст зводяться до наступного:

1. Узгодження цілей людського $і$ територіального розвитку (подолання існуючого дисбалансу при переході до більш раціональної структури економіки міста для побудови соціально орієнтованої моделі економічного зростання з чітким окресленням пріоритетів щодо потенційних можливостей гармонійного розвитку кожного окремого носія людського потенціалу).

2. Детальна конкретизація цільових об'єктів застосування та агентів реалізації стратегічних проектів та програм (досягнення більшої реалістичності та валідності індикаторів стратегічного людського розвитку, деталізованого моделювання сприятливих умов для максимально повного використання людських можливостей, виключення підміни понять в термінології концепції людського потенціалу).

3. Збалансоване нарощення економічної активності міст (посилення підприємницької, інвестиційної та креативної діяльності, ефективної інформаційно-консультаційної підтримки, налагодженого публічно-приватного діалогу, реалізації проектів високотехнологчіних екологічно безпечних виробництв, визнання людського потенціалу у якості вирішального ресурсу економічного піднесення).

4. Розбудова комфортного і безпечного міського середовища формування, збереження та відтворення людського потенціалу (розширення доступності якісних освітніх і медичних послуг, гармонізація параметрів міської інфраструктури, наближеної до особистісних пріоритетів розвитку людського потенціалу).

5. Врахування окремих поведінкових патернів та очікувань носіїв людського потенціалу (запровадження моніторингу проблемних сфер соціального та економічного розвитку, системи менеджменту якості та внутрішнього аудиту стратегічних програм, проведення аналітичної оцінки готовності громадян сприймати та підтримувати стратегічні зміни).

Висновки. Постіндустріальний характер розвитку економіки, 
нестабільність та невизначеність глобального середовища, вимоги сталого зростання призводять до зміщення уваги від проблематики формування людського потенціалу великих соціально-економічних систем до локального рівня, коли міста та урбанізовані території виступають в якості стратегічних центрів, драйверів нарощення потенційних можливостей людського розвитку. При здійсненні стратегічного планування на рівні міст концепція людського потенціалу розглядається в рамках характеристики сильних та слабких сторін, можливостей та загроз внутрішнього і зовнішнього середовища міста, та одночасно з тим у якості ключового чинника або ресурсу забезпечення сталого економічного зростання. В ході дослідження визначено, що найкращих показників стратегічного розвитку досягають міста та території, де економічна діяльність $\epsilon$ диференційованою з урахуванням соціально орієнтованої моделі, відбувається посилення інтеграційних процесів, застосовується людиноцентрований підхід, за якого нівелюється вплив негативної демографічної динаміки, відбувається вирівнювання розвитку соціального середовища, що сприятливо відображається на кількісних та якісних показниках формування, збереження, відтворення та реалізації людського потенціалу.

Сприятливі умови розвитку людського потенціалу дозволяють уникнути формування у носіїв людського потенціалу негативних поведінкових патернів забезпечення принаймні неубутного існування та спрямовувати основні зусилля особистісного зростання на досягнення максимального рівня креативності. За наявності відповідних стратегічних пріоритетів підвищуються позитивні очікування носіїв людського потенціалу щодо перспектив розвитку міста у відповідності із їх життєвими траєкторіями, що обґрунтовує посилену увагу до питання стратегічного розвитку людського потенціалу. 3 цією метою обґрунтовано ключові положення формування стратегії розвитку людського потенціалу, а саме потребу в погодженні спільного бачення людського і територіального розвитку, детальній адресації об'єктів застосування та агентів реалізації стратегічних проєктів та програм, балансування пріоритетів економічної активності, модернізації міського середовища, моніторингу зміни поведінки та очікувань носіїв людського потенціалу, що покликані ефективно долати виклики нової економіки, характерні для сучасного світу.

1. Schultz T. Investment in human capital: the role of education and of research. N.Y., 1971. 272 p. 2. Becker G. Human capital: theoretical and empirical analysis, with special reference to education (3rd ed.). University of Chicago Press. 1993. 3. Яковенко Р. В. Людський капітал та людський потенціал. Наукові праці 
Кіровоградського національного технічного університету. Економічні науки. 2013. Вип. 24. С. 186-193. 4. Шаульська Л. В. Людські ресурси нової економіки: ключові компоненти та ефективність регулювання. Економіка і організація управління. 2018. № 4(32). С. 7-16. 5. Непрядкіна Н. В. Формування людського потенціалу в сучасних умовах розвитку держав. Вісник ХНУ ім. Каразіна. Сер. Міжнародні відносини. Економіка. Країнознавство. Туризм. 2019. Вип. 10. С. 160-166. 6. Zhang L. Y. City development strategies and the transition towards a green urban economy. The Economy of Green Cities. 2013. № 3. P. 231-240. 7. Осипенко К. В., Клюшниченко $€$. $€$. Врахування ресурсних обмежень для сталого розвитку населених пунктів. Регіональна політика: історія, політико-правові засади, архітектура, урбаністика : зб. наук. праць. Київ-Тернопіль : «Бескиди», 2018. Вип. IV. Ч. 2. С. 86-90. 8. Poister Т., Streib G. Elements of strategic planning and management in municipal government: Status after two decades. Public Administration Review. 2005. 65(1). P. 45-56. 9. Raynor K. E., Doyon A., Beer T. Collaborative planning, transitions management and design thinking: Evaluating three participatory approaches to urban planning. Aust. Plan. 2017. Vol. 54. P. 215-224. 10. Wilson A., Tewdwr-Jones M., Comber R. Urban planning, public participation and digital technology: App development as a method of generating citizen involvement in local planning processes. Environ. Plan. B Urban Anal. City Sci. 2019. Vol. 46. Р. 286-302. 11. Урбаністична Україна: в епіцентрі просторових змін : монографія / за ред. К. Мезенцева, Я. Олійника, Н. Мезенцевої. Київ : Видавництво «Фенікс», 2017. 438 с. 12. Бліщук К. М. Інноваційні інструменти місцевого економічного розвитку. Ефективність державного управління. 2019. Вип. 2 (59). Ч. 2. С. 177-182. 13. Шаульська Л. В., Бойченко В. С. Стан та перспективи розвитку соціальної інфраструктури міста: суб'єктивний аспект. Ефективна економіка. $2017 . \quad$ № $10 . \quad$ URL: http://www.economy.nayka.com.ua/?op=1\&z=5790. (дата звернення: 30.10.2020). 14. Henderson Vernon. The Urbanization Process and Economic Growth: The So-What Question. Journal of Economic Growth. Springer, 2003. Vol. 8(1). P. 47-71. 15. Human Development Report. The next frontier. Human development and the Anthropocene. 2020. 412 p. 16. Realizing Human Potential in the Fourth Industrial Revolution An Agenda for Leaders to Shape the Future of Education, Gender and Work. World Economic Forum. 2017. 38 p. 17. Snegireva T., Kayachev G., Falaleev A., Kurgansky S. Human Potential in the System of Sustainable Development. E3S Web of Conferences. 2019. 134. 18. R. W. Kates, Th. M. Parris and A. A. Leiserowitz. What is Sustainable Development? Goals, Indicators, Values, and Practice. Environment: Science and Policy for Sustainable Development. Volume 47, 2005. Issue 3. Р. 8-21. 19. Метрополійні функції великих міст України: потенціал розвитку та перспективи реалізації : монографія / НАН України. Державна установа «Інститут регіональних досліджень ім. М.І. Долішнього НАН України»; наук. ред. М. І. Мельник. Львів, 2016. 552 с. 20. Панкратов Н.В. Развитие человеческого потенциала в условиях городской среды. Теория и практика общественного развития. 2014. № 1. С. 442-446. 21. Мегаполис для жизни. Краткие выводы исследования. 2018. 28 с. 22. Індекс конкурентоспроможності міст 2019/2020. Інститут економічних досліджень та політичних консультацій. Київ, 2020. 193 с. 23. Управління розвитком людського потенціалу територіальної громади в інноваційно-знаннєвому суспільстві / уклад. : Ю. О. Куц, В.В.Мамонова, С. В.Газарян. Київ : НАДУ, 2012. 44 с. 24. Потенціал розвитку територій: методологічні засади формування і нарощення : монографія / О. Ю. Бобровська, Т. А. Крушельницька, М. А. Латинін та ін. Дніпро : ДРІДУ НАДУ, 2017. 362 с. 25. Міста 2030. Модернізуйся або вмирай. Аналітичний звіт. Український інститут майбутнього. 2018. 116 c. 26. Petrova M., Koval V., 
Серія «Економічні науки»

Випуск 4(92) 2020 p.

Tepavicharova, M. Zerkal, A. Radchenko, A. Bondarchuk, N. The interaction between the human resources motivation and the commitment to the organization. Journal of Security and Sustainability Issues. 2020. Vol. 9. N. 3. P. 897-907. 27. Bantash, A., Koval, V., Bashynska, M., \& Kozlovtseva, V. Balanced territorial economic development in the conditions of providing stability of human resources management. Economics. Ecology. Socium. 2020. Vol. 4. N. 3. P. 58-66.

\section{REFERENCES:}

1. Schultz T. Investment in human capital: the role of education and of research. N.Y., 1971. 272 p. 2. Becker G. Human capital: theoretical and empirical analysis, with special reference to education (3rd ed.). University of Chicago Press. 1993. 3. Yakovenko R. V. Liudskyi kapital ta liudskyi potentsial. Naukovi pratsi Kirovohradskoho natsionalnoho tekhnichnoho universytetu. Ekonomichni nauky. 2013. Vyp. 24. S. 186-193. 4. Shaulska L. V. Liudski resursy novoi ekonomiky: kliuchovi komponenty ta efektyvnist rehuliuvannia. Ekonomika i orhanizatsiia upravlinnia. 2018. № 4(32). S. 7-16. 5. Nepriadkina N. V. Formuvannia liudskoho potentsialu v suchasnykh umovakh rozvytku derzhav. Visnyk KhNU im. Karazina. Ser. Mizhnarodni vidnosyny. Ekonomika. Krainoznavstvo. Turyzm. 2019. Vyp. 10. S. 160-166. 6. Zhang L. Y. City development strategies and the transition towards a green urban economy. The Economy of Green Cities. 2013. № 3. P. 231-240. 7. Osypenko K. V., Kliushnychenko Ye. Ye. Vrakhuvannia resursnykh obmezhen dlia staloho rozvytku naselenykh punktiv. Rehionalna polityka: istoriia, polityko-pravovi zasady, arkhitektura, urbanistyka : zb. nauk. prats. Kyiv-Ternopil : «Beskydy», 2018. Vyp. IV. Ch. 2. C. 86-90. 8. Poister T., Streib G. Elements of strategic planning and management in municipal government: Status after two decades. Public Administration Review. 2005. 65(1). P. 45-56. 9. Raynor K. E., Doyon A., Beer T. Collaborative planning, transitions management and design thinking: Evaluating three participatory approaches to urban planning. Aust. Plan. 2017. Vol. 54. P. 215-224. 10. Wilson A., Tewdwr-Jones M., Comber R. Urban planning, public participation and digital technology: App development as a method of generating citizen involvement in local planning processes. Environ. Plan. B Urban Anal. City Sci. 2019. Vol. 46. P. 286-302. 11. Urbanistychna Ukraina: v epitsentri prostorovykh zmin : monohrafiia / za red. K. Mezentseva, Ya. Oliinyka, N. Mezentsevoi. Kyiv : Vydavnytstvo «Feniks», 2017. 438 s. 12. Blishchuk K. M. Innovatsiini instrumenty mistsevoho ekonomichnoho rozvytku. Efektyvnist derzhavnoho upravlinnia. 2019. Vyp. 2 (59). Ch. 2. S. 177-182. 13. Shaulska L. V., Boichenko V. S. Stan ta perspektyvy rozvytku sotsialnoi infrastruktury mista: subiektyvnyi aspekt. Efektyvna ekonomika. 2017. № 10. URL: http://www.economy.nayka.com.ua/?op=1\&z=5790. (data zvernennia: 30.10.2020). 14. Henderson Vernon. The Urbanization Process and Economic Growth: The So-What Question. Journal of Economic Growth. Springer, 2003. Vol. 8(1). P. 47-71. 15. Human Development Report. The next frontier. Human development and the Anthropocene. 2020. 412 p. 16. Realizing Human Potential in the Fourth Industrial Revolution An Agenda for Leaders to Shape the Future of Education, Gender and Work. World Economic Forum. 2017. 38 p. 17. Snegireva T., Kayachev G., Falaleev A., Kurgansky S. Human Potential in the System of Sustainable Development. E3S Web of Conferences. 2019. 134 s. 18. R. W. Kates, Th. M. Parris and A. A. Leiserowitz. What is Sustainable Development? Goals, Indicators, Values, and Practice. Environment: Science and Policy for Sustainable Development. Volume 47, 2005. Issue 3. P. 8-21. 19. Metropoliini funktsii velykykh mist Ukrainy: potentsial rozvytku ta perspektyvy realizatsii : monohrafiia / NAN Ukrainy. Derzhavna ustanova «Instytut rehionalnykh doslidzhen 
im. M. I. Dolishnoho NAN Ukrainy»; nauk. red. M. I. Melnyk. Lviv, 2016. 552 s. 20. Pankratov N. V. Razvitie chelovecheskogo potentsiala v usloviyah gorodskoy sredyi. Teoriya i praktika obschestvennogo razvitiya. 2014. № 1. S. 442-446. 21. Megapolis dlya jizni. Kratkie vyivodyi issledovaniya. 2018. 28 s. 22. Indeks konkurentospromozhnosti mist 2019/2020. Instytut ekonomichnykh doslidzhen ta politychnykh konsultatsii. Kyiv, 2020. 193 s. 23. Upravlinnia rozvytkom liudskoho potentsialu terytorialnoi hromady $v$ innovatsiino-znannievomu suspilstvi / uklad. : Yu. O. Kuts, V. V. Mamonova, S. V. Hazarian. Kyiv : NADU, 2012. 44 s. 24. Potentsial rozvytku terytorii: metodolohichni zasady formuvannia i naroshchennia : monohrafiia / 0. Yu. Bobrovska, T. A. Krushelnytska, M. A. Latynin ta in. Dnipro: DRIDU NADU, 2017. 362 s. 25. Mista 2030. Modernizuisia abo vmyrai. Analitychnyi zvit. Ukrainskyi instytut maibutnoho. 2018. 116 s. 26. Petrova M., Koval V., Tepavicharova M., Zerkal A., Radchenko A., Bondarchuk $\mathrm{N}$. The interaction between the human resources motivation and the commitment to the organization. Journal of Security and Sustainability Issues. 2020. Vol. 9. N. 3. P. 897-907. 27. Bantash A., Koval V., Bashynska M. \& Kozlovtseva V. Balanced territorial economic development in the conditions of providing stability of human resources management. Economics. Ecology. Socium. 2020. Vol. 4. N. 3. P. 5866.

Tomchuk 0. V. [1; ORCID ID: 0000-0002-1817-7483] Candidate of Economics (Ph.D.), Associate Professor

'Vasyl' Stus Donetsk National University, Vinnytsia

\section{CONCEPTUAL PROVISIONS OF THE STRATEGY FORMATION OF HUMAN POTENTIAL DEVELOPMENT OF CITIES IN THE NEW ECONOMY}

The article is devoted to the study of strategic human development of cities in the context of the new economy, overcoming the latest postindustrial, innovation and technological challenges of human-centered change of society, defining the role of human potential in transforming cities into dynamic centers of social and economic growth. Strategic planning of urban human development is designed to increase the scientific feasibility and practical significance of goals, management decisions, forecast scenarios and local development programs in order to consider better the interests and needs of human resources capable to ensure long-term quality dynamics of local and national growth. The purpose of the article is to substantiate scientifically conceptual provisions of forming the strategy of urban human potential development considering challenges of the new economy and post-industrial society. An assessment of the strategic priorities of the most competitive Ukrainian cities was made in order to determine which aspects of the formulation of the urban strategic development vision can influence positively the formation of human potential. The necessity of consolidation the efforts to form comfort urban environment focused on formation, preservation, development and effective 
use of human potential of cities was determined. The key provisions of human resources development strategy were formulated: coherence of common vision and formulation of goals, detailed addressing of application objects and agents, balancing of human and territorial development priorities, active modernization of urban space and infrastructure, considering behavioral patterns and expectations. Favorable conditions for the development of human potential allow to avoid the formation of human potential negative behavioral patterns to ensure at least a steady existence and to direct the main efforts of personal growth to achieve the maximum level of creativity. In the presence of appropriate strategic priorities, the positive expectations of human resources bearers regarding the prospects of the urban development in accordance with their life trajectories increase, which justifies the increased attention to the issue of strategic human development.

Keywords: strategic development; human potential of cities; postindustrial economy; competitiveness of cities.

Томчук О. В. ${ }^{[1 ; 0 R C I D ~ I D: ~ 0000-0002-1817-7483] ~}$ к.э.н., доцент

'Донецкий национальный университет имени Василия Стуса, г. Винница

\title{
КОНЦЕПТУАЛЬНЫЕ ПОЛОЖЕНИЯ ФОРМИРОВАНИЯ СТРАТЕГИИ РАЗВИТИЯ ЧЕЛОВЕЧЕСКОГО ПОТЕНЦИАЛА ГОРОДОВ В НОВОЙ ЭКОНОМИКЕ
}

\begin{abstract}
Статья посвящена изучению стратегического развития человеческого потенциала городов В контексте новой экономики, преодолению новейших постиндустриальных, инновационных и технологических вызовов ориентированных на человека изменений в обществе, определению роли человеческого потенциала в превращении городов в динамичные центры социально-экономического роста. Стратегическое планирование развития городского человеческого потенциала направлено на повышение научной осуществимости и практической значимости целей, управленческих решений, прогнозных сценариев и местных программ развития с целью более эффективного рассмотрения интересов и потребностей людских ресурсов, способных обеспечить долгосрочную динамику качества местного и национального роста. Целью статьи является научное обоснование концептуальных положений формирования стратегии развития человеческого потенциала городов с учетом вызовов новой экономики и постиндустриального общества. Проводится оценивание стратегических приоритетов наиболее конкурентоспособных украинских городов с целью определения того, какие аспекты формирования концепции
\end{abstract}


стратегического развития могут положительно повлиять на формирование ихнего человеческого потенциала. Определена необходимость консолидации усилий по формированию комфортной городской среды, направленных на формирование, сохранение, развитие и эффективное использование человеческого потенциала городов. Сформулированы ключевые положения стратегии развития человеческих ресурсов: согласованность общего видения и формулировки целей, детальное рассмотрение объектов и агентов применения, баланс приоритетов развития человека и территории, активная модернизация городского пространства и инфраструктуры, рассмотрение поведенческих моделей и ожиданий. Благоприятные условия для развития человеческого потенциала позволяют избежать формирования у человека потенциальных негативных поведенческих моделей, обеспечить, как минимум, устойчивое существование и направить основные усилия личностного роста на достижение максимального уровня творчества. При наличии надлежащих стратегических приоритетов возрастают позитивные ожидания носителей человеческих ресурсов относительно перспектив развития городов в соответствии с жизненными траекториями, что оправдывает повышенное внимание $к$ вопросу стратегического развития человеческого потенциала.

Ключевые слова: стратегическое развитие; человеческий потенциал городов; постиндустриальная экономика; конкурентоспособность городов. 